\title{
POLA KONFLIK AGAMA DI WILAYAH PLURAL: STUDI KASUS PENDIRIAN RUMAH IBADAH DI KOTA JAMBI
}

\author{
Abdul Halim \\ UIN Sulthan Thaha Saifuddin Jambi \\ Email: abdulhalim@uinjambi.ac.id

\section{Zaki Mubarak} \\ UIN Sulthan Thaha Saifuddin Jambi \\ Email: zakimubarak@uinjambi.ac.id
}

\begin{abstract}
Jambi City has the potential for social conflict, especially religious conflict related to the establishment of houses of worship. The history of religious conflict in Indonesia notes that houses of worship have become a source of potential conflict which often leads to destruction and burning. Related to this, it is necessary to make efforts to prevent this conflict is not prolonged, one option is by revitalizing of the local cultural wisdom that grows in each region. This study was conducted using a qualitative research approach. This research was conducted in Telanaipura, Alam Barajo, and Kotabaru in Jambi City. The results of this study found that as a pluralistic area, Jambi City was also not spared from the conflict of the establishment of places of worship that occurred in three regions, but was not prolonged. The pattern of conflict began with peaceful actions by Muslim communities against the construction of churches in Muslim-majority settlements. The conflict did not continue to be anarchic because the local wisdom of the people of Jambi City resolved cases through consensus with tuo-tuo tengganai, traditional leaders, and religious leaders so that it could be resolved by traditional leaders, religious leaders and local governments Jambi City.
\end{abstract}

Keywords: Religious Conflict, Conflict Pattern, Minority, Pluralistic Area

\section{Abstrak}

Kota Jambi memiliki potensi konflik sosial, khususnya konflik agama terkait pendirian rumah ibadah. Sejarah konflik agama di Indonesia mencatat bahwa rumah ibadah menjadi salah satu sumber konflik potensial yang seringkali berujung pada perusakan dan pembakaran. 
Terkait hal tersebut, perlu dilakukan upaya agar konflik ini tidak berkepanjangan, salah satunya dengan revitalisasi kearifan budaya lokal yang tumbuh di masing-masing daerah. Penelitian ini dilakukan dengan pendekatan penelitian kualitatif dengan mengambil objek lokasi di Telanaipura, Alam Barajo, dan Kotabaru Kota Jambi. Hasil penelitian ini menemukan bahwa sebagai kawasan majemuk, Kota Jambi juga tak luput dari konflik pendirian rumah ibadah yang terjadi di tiga wilayah, namun tidak berkepanjangan. Pola konflik diawali dengan aksi damai masyarakat muslim terhadap pendirian gereja di pemukiman mayoritas muslim. Konflik tersebut tidak berlanjut menjadi anarkis karena kearifan lokal masyarakat Kota Jambi menyelesaikan perkara melalui mufakat bersama tuo-tuo tengganai, tokoh adat, dan tokoh agama sehingga dapat diselesaikan oleh tokoh adat, tokoh agama dan pemerintah daerah di Kota Jambi.

Kata Kunci: Konflik Agama, Pola Konflik, Minoritas, Area Pluralistik

\section{Pendahuluan}

Terjadinya konflik dalam sebuah tatanan masyarakat yang majemuk dan hidup di wilayah yang heterogen merupakan hal yang biasa dan seringkali terjadi khususnya dalam sejarah kehidupan bermasyarakat. ${ }^{1}$ Hal ini karena secara teoretik, pluralitas yang melekat pada sebuah wilayah berpotensi menyebabkan perpecahan atau konflik di antara masyarakat yang ada di dalamnya. ${ }^{2}$ Negara seperti Inggris misalnya, memiliki sejarah konflik yang panjang dengan suku bangsa Scot dan suku bangsa Welsh, begitu juga dengan Perancis yang masih terus berkonflik dengan suku bangsa Breton. Wilayah-wilayah heterogen di Indonesia juga mengalami 'efek' dari predikat plural tersebut, sehingga banyak terjadi konflik yang menimbulkan kerusakan yang besar seperti konflik Poso

${ }^{1}$ Amos Sukamto. Ketegangan Antar Kelompok. Agama Pada Masa Orde Lama Sampai Awal Orde Baru: Dari Konflik Perumusan Ideologi Negara Sampai Konflik. Fisik. Jurnal Teologi Indonesia 1/1 (Juli 2013).

${ }^{2}$ Novri Susan. Sosiologi Konflik: Teori-Teori Dan Analisis. (Jakarta: PT. Kencana Media Grup, 2019), 7. 
(1998-2001), ${ }^{3}$ Sampit, Sambas Kalimantan Barat (1997,1999-2001), Maluku, Maluku Utara (1999), ${ }^{4}$ dan konflik Aceh (1999-2005). ${ }^{5}$

Di antara sekian banyak sumber konflik (suku, ekonomi dan politik), agama diyakini merupakan penyebab pertentangan sosial yang paling paradoks. ${ }^{6}$ Konflik terbesar yang pernah terjadi terjadi dalam sejarah dunia mencatata bahwa faktor agama merupakan pemicu utamanya. Sebagai contoh konflik agama yang menyebabkan terjadinya peperangan hingga berabad-abad yakni konflik antara umat Islam dengan Kristen di Eropa yang dikenal dengan perang Salib (1096-1271 M).

Agama sebagai salah satu sumber konflik memiliki beberapa sebab, yang menurut Ahmad Suedy pertentangan terkait pendirian tempat ibadah merupakan penyebab utama terjadinya perselisihan sosial di ranah agama yang tidak jarang berujung perusakan dan pembakaran di Indonesia. ${ }^{8}$ Hal ini mengemuka karena eksistensi agama di tengah masyarakat direpresentasikan melalui wajah ganda. ${ }^{9}$ Pada satu sisi, agama muncul dengan wajah positif melalui seperangkat moral dan nilai yang baik bagi para pemeluknya, akan tetapi di sisi lainnya, agama mengemuka dengan wajah negatif karena menjadi sumber serangkaian konflik yang terjadi karena

3Igneus Alganih. Konflik Poso (Kajian Historis Tabun 1998-2001). Jurnal Criksetra, Volume 5, Nomor 10, Agustus, 2016.

4Jamin Safi. Konflik Komunal: Maluku 1999-2000. Jurnal Pendidikan dan Sejarah, Volume 12 No. 2, Maret 2017.

${ }^{5}$ Kasus ini dikategorikan sebagai kasus besar antara lain berdasarkan tingkat kekerasan dan pertentangan yang terjadi, lama waktu terjadi konflik, jumlah korban jiwa dan kerusakan yang terjadi.

${ }^{6}$ Andik Wahyun Muqoyyidin. Potret Konflik Bernuansa Agama di Indonesia (Signifikansi Model Resolusi Berbasis Teologi Transformatif). ANALISIS: Jurnal Studi Keislaman, 2013, Volume XII, No. 2, Desember 2012, 315-340.

${ }^{7}$ Firdaus S.Yunus. Konflik. Agama di Indonesia: Problem dan Solusi Pemecahannya. Substantia, Volume 16 Nomor 2, Oktober 2014. 217-228. Retrieved from http://substantiajurnal.org.

${ }^{8}$ Ahmad Suaedy. Politisasi Agama dan Konflik Komunal: Beberapa Isu Penting di Indonesia. (Jakarta: The Wahid Institute, 2007), 247.

${ }^{9}$ Charles Kimball. When Religion Becomes Evil. (USA: Harper Collins, 2008), 33.

TAJDID vol. 19, No. 1, Januari - Juni $2020 \mid 87$ 
kesalahfahaman pemeluknya dalam memahaminya dan sikap ekslusifnya. Eksistensi agama yang berwajah ganda ini memunculkan banyak perdebatan di kalangan ahli dan pemikir. Agama diakui sebagai kebutuhan mendasar bagi manusia, karena tidak pernah ditemukan dalam sejarah ada masyarakat yang tidak beragama. ${ }^{10}$

Dari beberapa konflik yang tejadi seputar rumah ibadah, sebagian besar disebabkan atas penolakan mayoritas penganut agama setempat terhadap rumah ibadah agama minoritas yang dibangun di lokasi tersebut. ${ }^{11}$ Selain penolakan, permasalahan rumah ibadah biasanya disebabkan argumen mengenai rencana pembangunan yang tidak memenuhi syarat dalam peraturan SKB 2 Menteri yang telah ditetapkan pemerintah dalam Peraturan Bersama Menteri No. 9 Tahun 2006 dan No. 8 Tahun 2006 yang di dalamnya mengatur mengenai pendirian rumah ibadah. ${ }^{12}$

Menurut catatan Center for Religious and Cross-cultural Studies (CRCS) Universitas Gadjah Mada, pada tahun 2008 termasuk 12 kasus konflik seputar rumah ibadah, sementara pada tahun 2009 terdapat 18 kasus dan pada tahun 2010 terdapat 39 kasus. $^{13}$ Sementara menurut data Kompas.com (08/01/2019), sepanjang 2018 Lembaga Bantuan Hukum (LBH) se-Indonesia yang bernaung di bawah Yayasan Lembaga Bantuan Hukum Indonesia (YLBHI) telah menangani 15 kasus terkait pelanggaran hak atas kebebasan beragama dan berkeyakinan antara lain kasus konflik rumah ibadah di Tanjung Balai Asahan Sumatera Utara, ${ }^{14}$ Konflik

${ }^{10}$ Bustanuddin Agus. Agama dalam Kehidupan Manusia: Pengantar Antropologi Agama. (Jakarta: PT. RajaGrafindo Persada, 2006), 33.

${ }^{11}$ Firdaus S.Yunus. Konflik Agama di Indonesia: Problem dan Solusi Pemecahannya. Substantia, Volume 16 Nomor 2, Oktober 2014. 217-228. Retrieved from http://substantiajurnal.org.

${ }^{12}$ Kustini Dkk. Efektivitas Sosialisasi PBM No.9 dan 8 tabun 2006. (Jakarta: CV. Prasasti, 2009), 49.

${ }^{13}$ Zaenal Abidin Bagir, Dkk. Laporan Tahunan Kebidupan Beragama di Indonesia Tabun 2008-2011. (Yogyakarta: CRCS UGM, 2011).

${ }^{14}$ Konflik yang terjadi di Tanjung Balai Asahan ini bermula dengan adanya pembangunan dan peletakan Patung Buddha Amithaba di Vihara Tri Ratna yang 
Aceh Singkil, ${ }^{15}$ Tolikara Papua, ${ }^{16}$ dan konflik rumah ibadah lainnya. ${ }^{17}$

Sebagaimana disebutkan sebelumnya bahwa wilayah yang memiliki tingkat pluralitas tinggi berpotensi terjadinya konflik. Kategori wilayah yang plural juga ada pada Kota Jambi, kota utama dan paling padat di Provinsi Jambi. Berdasarkan pada aspek geografis dan demografis, Kota Jambi memiliki luas wilayah sebesar 205,38 km dengan delapan kecamatan dan jumlah penduduk sebanyak 576.067 jiwa, dengan rincian laki-laki sebanyak 289.713 jiwa dan perempuan sebanyak 286.354 jiwa (BPS Kota Jambi, 2019). Berdasarkan aspek sosiologis, komposisi penduduk Kota Jambi berdasarkan etnis cukup beragam, mulai Jawa, Sunda, Palembang, Batak, Minang, Bugis, Banjar, Arab, India dan China, meskipun etnis Melayu menjadi kelompok mayoritas, ${ }^{18}$ dan memeluk beragam agama, seperti Islam (sebagai mayoritas), Kristen, Katholik, Hindu, Budha dan Khong Hu Chu (BPS Kota Jambi, 2019). ${ }^{19}$

Sejalan dengan konsepsi pluralitas menghasilkan konflik, maka di Kota Jambi juga pernah terjadi konflik bernuansa agama. ${ }^{20}$ Secara historis kronologis berawal dari kehadiran para tokoh

dianggap warga Muslim Tanjung Balai mengganggu kenyamanan ibadah mereka. Kemudian terjadilah pembakaran Vihara yang terjadi pada tanggal 29 Juli 2016 melibatkan sentiment budaya (kultural) (Hesni Ismiati, Konflik Antar Warga di Tanjung Balai Asahan Sumatera Utara, Jurnal EmpirikaVol.2 No.1, Mei. 2017).

${ }^{15}$ Mallia Hartani, Analisis Konflike Antar Umat Beragama di Aceb Singkil, Jurnal Kolaborasi Resolusi Konflik, Volume 2, Nomor 2, 2020.

${ }^{16}$ Mohd. Rasyid, Peredam Konflik. Agama: Studi Analisis Penyelesaian di Tolikara Papua 2015, Jurnal Afkaruna Vol. 13 No.1 Juni 2017.

${ }^{17}$ https:// nasional.kompas.com/read/2019/01/08/18584911/ada-15kasus-pelanggaran-hak-beragama-di-2018.

${ }^{18}$ Lindayanty. Jambi dalam Sejarah 1500-1942. (Jambi: Dinas Kebudayaan dan Pariwisata Provinsi Jambi, 2013), 209.

${ }^{19}$ Badan Pusat Statistik (2019). Kota Jambi dalam angka 2019. Kota Jambi: BPS Kota Jambi.

${ }^{20}$ Abdul Halim \& Pahrudin, HM. The Role of Local Wisdom as Religious Conflict Resolution in Jambi City. (Walisongo: Jurnal Penelitian Sosial Keagamaan, Vol.27, No.2, 2019). 353-374. DOI: http://dx.doi.org/10.21580/ws.27.2.4358. 
agama Kristen Batak yang datang ke daerah Penyengat Rendah Kecamatan Telanaipura Kota Jambi pada tahun 1980, dalam konteks bantuan musibah banjir. Masyarakat yang menerima sembako, semuanya beragama Islam, diminta untuk menandatangani lembaran kertas penerima sembako. Ironisnya, lembaran tandatangan penerima sembako ini kemudian disalahgunakan oleh Kelompok Tokoh Agama Kristen Batak untuk persyaratan pendirian balai pertemuan agama Kristen di daerah tersebut, sebagai persyaratan maupun bukti dukungan masyarakat setempat. Balai pertemuan ini lama kelamaan disulap menjadi gereja yang lokasinya hanya sekitar 300 meter dari bangunan masjid masyarakat setempat. Tentu kehadiran rumah ibadat Gereja ini direspon penolakan oleh masyarakat setempat yang mayoritas Muslim yang merasa telah diperdaya dan tidak pernah memberikan persetujuan. ${ }^{21}$

Terkait dengan hal di atas, menarik untuk melihat bagaimana pola konflik agama, terutama terkait dengan pendirian tempat ibadah di Kota Jambi. Sebagai wilayah paling plural di Provinsi Jambi, Kota Jambi sangat berpotensi menimbulkan gesekan sosial di tengah-tengah masyarakat. Apalagi dikaitkan dengan pluralitas agama Kota Jambi yang menjadi salah satu penyebab mengemukanya konflik, jika berkaca pada kasus-kasus yang terjadi di berbagai wilayah plural di Indonesia.

Penelitian ini dilakukan menggunakan pendekatan penelitian kualitatif, yaitu pendekatan yang memberi peluang kepada peneliti untuk dapat melakukan deskripsi dan interpretasi secara detail agar mendapatkan pemahaman secara holistik. ${ }^{22}$ Jenis penelitian ini adalah penelitian studi kasus (case study), yaitu jenis penelitian yang dapat diartikan sebagai suatu pendekatan untuk mempelajari,

${ }^{21}$ Secara lebih lanjut dan detail kasus pendirian Gereja di Penyengat Rendah Kecamatan Telanaipura Kota Jambi ini akan dibahas pada Bagian Pembahasan dengan pola penyelesaian konflik yang terjadi.

${ }^{22}$ Amir B. Marvasti. Qualitative Research in Sociology. (London: SAGE Publications, 2004), 7. 
menerangkan, atau menginterpretasikan suatu kasus (case) dalam konteksnya secara natural tanpa adanya intervensi dari pihak luar. ${ }^{23}$ Lebih khusus lagi, penelitian ini adalah penelitian studi kasus instrumental (instrumental case study) yang digunakan untuk meneliti suatu kasus tertentu sehingga dapat disajikan sebuah perspektif tentang isu atau perbaikan suatu teori. ${ }^{24}$

Penelitian ini dilakukan di Kota Jambi, khususnya terhadap tiga wilayah, yaitu: di Kelurahan Aur Duri Kecamatan Telanaipura kota Jambi, di Kelurahan Simpang Rimbo Kecamatan Alam Barajo kota Jambi, dan di Kelurahan Kenali Asam Bawah Kecamatan Kotabaru Kota Jambi. Alasan pengambilan setting lokasi khusus tiga daerah di Kota Jambi ini adalah bahwa ketiga wilayah ini merupakan daerah terpadat dan paling banyak memiliki tempattempat ibadah selain masjid di Kota Jambi. Sebagaimana yang disyaratkan dalam penelitian kualitatif dengan menggunakan metode studi kasus, maka data dikumpulkan dari beberapa sumber, yaitu: melalui dokumen dan rekaman arsip, wawancara, pengamatan langsung, (participant observation) dan perangkat fisik lainnya. ${ }^{25}$ Data primer dari penelitian ini adalah dokumen dan arsip sejarah pendirian rumah ibadah di Kota Jambi, dan orang-orang yang menjadi key informan antara lain adalah Ketua Lembaga Adat Melayu Kota Jambi dan orang-orang yang berkaitan langsung dengan peristiwa yang terjadi. Sebagai upaya menganalisis data yang sudah didapatkan dan dikumpulkan, maka digunakan teknik analisis data kualitatif yang dilakukan dengan melalui tiga cara,

23J. W. Creswell. Qualitative Inquiry and Research Design: Choosing Among Five Traditions (2nd ed.). Thousand Oaks. (London, New Delhi: Sage Publications, 2007).

${ }^{24}$ Denzin \& Lincoln. Handbook of Qualitative Research (Dariyanto, Badrus Samsul Fata, Abi, \& John Rinaldi, Trans. (Yogyakarta: Pustaka Pelajar, 2009). 301.

${ }^{25}$ R. K. Yin. Studi Kasus: Desain dan Metode (M. Djauzi Mudzakir, Trans.) (Jakarta: PT. RajaGrafindo Persada, 2004). 103-118. 
yaitu: reduksi data (reducing data), penyajian data (displaying data), dan penarikan kesimpulan atau drawing conclusion. ${ }^{26}$

\section{Konsep Konflik}

Berdasarkan perspektif etimologis, konflik berasal dari bahasa Latin 'Configere' yang diartikan sebagai saling memukul, kemudian diadopsi oleh bahasa Inggris menjadi 'Conflict'. ${ }^{27}$ Secara terminologis, konflik dipahami oleh banyak kalangan dalam beragam pengertian. Novri Susan misalnya, mengartikan konflik sebagai pertentangan yang ditandai oleh pergerakan dari beberapa pihak sehingga terjadi persinggungan, ${ }^{28}$ sementara Fisher memaknainya sebagai hubungan antara dua pihak atau lebih yang memiliki, atau merasa memiliki sasaran-sasaran yang tidak sejalan. ${ }^{29}$ Adapun Roxane S. Lulops dan Dudley D. Chan mendefinisikan konflik sebagai dua atau lebih reaksi yang bertentangan terhadap suatu peristiwa, atau perbedaan antara dua individu, adanya saling permusuhan antara kelompok, atau adanya suatu masalah yang harus diselesaikan. ${ }^{30}$ Pada konteks yang sama, Soekanto (2003) memahami konflik sebagai interaksi sosial yang terjadi antara dua orang (kelompok) atau lebih yang salah satu pihak berusaha menyingkirkan pihak lainnya dengan cara menghancurkannya atau membuatnya tidak berdaya. ${ }^{31}$ Menurut Wirawan, konflik adalah proses pertentangan yang diekspresikan di antara dua pihak atau lebih yang saling tergantung mengenai objek yang menjadi konflik, menggunakan pola perilaku dan interaksi konflik yang

${ }^{26}$ M. B. Miles, \& A. M. Huberman. Analisis data kualitatif. (Tjetjep Rohendi Rohidi, Trans.). (Jakarta: Universitas Indonesia Press, 1992), 15-21.

${ }^{27}$ Ida Bagus Wirawan,. Teori-Teori Sosial dalam Tiga Paradigma. (Jakarta: Kencana Prenada Media Group, 2012), 4.

${ }^{28}$ Novri Susan. Sosiologi Konflik: Teori-Teori Dan Analisis. Jakarta: PT. Kencana Media Grup, 2019), xvii.

${ }^{29}$ Simon Fisher, dkk. (2009). Mengelola Konflik: Keterampilan dan Strategi untuk. Bertindak. (Jakarta: British Council, 2009), 4.

${ }^{30}$ Roxane S.Lulops, and Dudley D. Chan. Conflict From Theory to Action. (USA: Allyn \& Bacon, 2000), 3.

${ }^{31}$ Soerjono Soekanto. Sosiologi: Suatu Pengantar, (Jakarta: PT. RajaGrafindo Persada, 2013), 33. 
menghasilkan keluaran konflik. ${ }^{32}$ Konflik juga dimaknai sebagai relasi sosial antar aktor sosial yang ditandai oleh pertentangan atau perselisihan dan kemarahan, baik dinyatakan secara terbuka ataupun tidak, dalam rangka mencapai keinginan atau tujuan masing-masing. ${ }^{33}$

Karl Marx, Ralf Dahrendorf, George Simmel, dan Lewis Coser sebagai tokoh-tokoh utama konflik mengatakan bahwa konflik adalah pertentangan antara satu individu dengan individu lain, atau antara satu kelompok dengan kelompok lain. ${ }^{34}$ Sebetulnya, konflik dapat dilihat dari dua segi. Dari segi positif, konflik dapat mendinamiskan kelompok-kelompok dalam masyarakat. Konflik dapat memacu bagi terjadinya kompetisi yang sehat, orang berupaya untuk menjadi lebih baik dari yang lainnya. Konflik bisa menjadi tahap awal perubahan sosial. Dari segi negatif, konflik merupakan salah satu masalah yang perlu diatasi. Konflik yang sengit dapat memicu perselisihan dan permusuhan yang tajam, yang mengganggu suasana antar kelompok dalam masyarakat. ${ }^{35}$

Oleh karena konflik di masyarakat merupakan sesuatu yang tidak bisa dielakkan, maka yang perlu diketahui adalah apakah konflik itu ada atau tidak ada, tapi bagaimana intensitas dan tingkat kekerasannya, dan dalam bentuk apa konflik itu, apakah menyangkut masalah fundamental atau isu-isu sekunder, bertentangan tajam atau sekadar perbedaan pandangan. Intensitas konflik menunjuk pada tingkat pengeluaran energi dan keterlibatan dari pihak-pihak (kelompok-kelompok) yang berkonflik, sedangkan

${ }^{32}$ Ida Bagus Wirawan. Teori-Teori Sosial dalam Tiga Paradigma. (Jakarta: Kencana Prenada Media Group, 2012), 5.

${ }^{33}$ Rilus A. Kinseng. Konflik Nelayan. (Jakarta: Yayasan Obor IndonesiaDepartemen Sains Komunikasi dan Pengembangan Masyarakat Fakultas Ekologi Manusia Institut Pertanian Bogor, 2014), 12.

${ }^{34}$ Sindung Haryanto. Spektrum Teori Sosial; Dari Klasik Hingga Postmodern. (Yogyakarta: Ar-Ruz Media, 2012), 15.

${ }^{35}$ Doyle Paul Johnson. Teori Sosiologi Klasik dan Modern. (Jakarta: Gramedia Pustaka Utama, 1998), 21. 
kekerasan konflik menyangkut alat atau sarana yang digunakan dalam situasi konflik, mulai dari negosiasi hingga saling menyerang secara fisik. Konflik antar kelompok yang menyangkut masalah prinsip dasar (fundamental) akan menimbulkan pertentangan antar kelompok yang lebih serius dibandingkan bila masalahnya sekadar bersifat sekunder atau dinilai tidak penting. ${ }^{36}$

Sebagai sebuah fenomena sosial, kemunculan konflik tentu merupakan dampak dari sesuatu yang menjadi penyebabnya. Kalangan sosiolog menyebut bahwa faktor utama yang menyebabkan terjadinya konflik adalah perebutan atas sumbersumber kepemilikan, status sosial dan kekuasaan yang jumlahnya sangat terbatas dan tidak merata dalam masyarakat. ${ }^{37}$ Terkait dengan konteks ini, Fisher mengajukan beberapa teori yang dilakukan sebagai upaya untuk menjelaskan faktor-faktor penyebab terjadinya konflik dalam masyarakat.

1. Berdasarkan Teori Hubungan Masyarakat, terjadinya konflik dalam masyarakat merupakan akibat dari polarisasi yang terus berlangsung serta ketidakpercayaan (untrust) dan permusuhan di antara kelompok yang berbeda dalam suatu masyarakat. Atas dasar demikian, sebagai upaya mencegah terjadinya konflik, maka yang perlu dilakukan adalah meningkatkan komunikasi dan pengertian antara kelompok-kelompok yang mengalami konflik serta meningkatkan toleransi agar masyarakat dapat saling menerima keragaman.

2. Teori Negosiasi Prinsip beranggapan bahwa faktor penyebab terjadinya konflik adalah ketidakselarasan dan perbedaan pandangan tentang konflik oleh pihak-pihak yang terlibat di dalamnya. Sebagai upaya mengatasi problem ini, maka yang harus dilakukan adalah memisahkan sentimen-sentimen pribadi dan menegosiasikan kepentingan bersama serta

${ }^{37}$ Adon Nasrullah Jamaludin. Agama dan Konflik Sosial: Studi Kerukunan Umat Beragama, Radikalisme dan Konflik Antarumat Beragama. (Bandung: Pustaka Setia, 2015), 2. 
berupaya mencapai kesepakatan yang menguntungkan bagi kedua pihak yang berkonflik.

3. Menurut Teori Kebutuhan Manusia, konflik merupakan dampak dari tidak terpenuhinya kebutuhan-kebutuhan dasar manusia. Dengan demikian, pencegahan yang dapat dilakukan adalah mengusahakan secara bersama pemenuhan kebutuhankebutuhan dasar dan menghasilkan pilihan-pilihan alternatif untuk memenuhinya.

4. Teori Identitas mengatakan bahwa konflik muncul karena adanya identitas yang terancam yang seringkali disebabkan tidak selesainya problem-problem yang ada di masa lalu. Dengan demikian, pencegahannya dapat dilakukan dengan cara membangun empati dan rekonsiliasi di antara pihak-pihak yang terlibat dan membentuk rekonsiliasi.

5. Menurut Teori Kesalahpahaman Antarbudaya, faktor penyebab munculnya konflik adalah karena ketidakcocokan dalam cara-cara komunikasi di antara budaya yang berbeda. Sebagai upaya mencegahnya, maka yang harus dilakukan adalah memperkenalkan pengetahuan budaya pihak lain, mengurangi pelabelan (stereotype) negatif terhadap pihak lain, mengefektifkan komunikasi antarbudaya.

6. Teori Transformasi mengatakan bahwa munculnya konflik karena ketidaksetaraan dan ketidakadilan sosial yang dialami oleh suatu kelompok dalam masyarakat. Pencegahan munculnya konflik menurut teori ini adalah dengan cara mengubah struktur yang menimbulkan ketimpangan tersebut, meningkatkan kerjasama berbagai pihak dan mengembangkan berbagai kegiatan yang bermaterikan pemberdayaan, keadilan, perdamaian dan rekonsiliasi. ${ }^{38}$

${ }^{38}$ Simon Fisher, dkk. Mengelola Konflik: Keterampilan dan Strategi untuk Bertindak. (Jakarta: British Council, 2009), 8-9. 


\section{Konsep Rumah Ibadah}

Sebagaimana diketahui bahwa pendirian rumah ibadah merupakan bentuk ketaatan seorang manusia terhadap agama yang dianutnya. Hal ini karena rumah ibadah merupakan kebutuhan setiap umat beragama yang menjadi tempat melaksanakan ajaran agamanya. Apabila dibawa dalam konteks kebebasan beragama, hal ini tentu merupakan hak dan kebebasan dalam mengekspresikan kebebasan beragama. Namun demikian, persoalannya adalah pendirian rumah ibadah bukan semata-mata berdirinya sebuah bangunan ibadah agama tertentu, tetapi ada indikasi klaim jumlah pemeluk agama tertentu di sebuah wilayah. Jumlah pemeluk agama yang banyak salah satunya ditunjukkan dengan hadirnya rumah ibadah. Banyaknya jumlah pemeluk agama tertentu di sebuah wilayah dianggap sebagai keuntungan sosial bagi kalangan tertentu, apalagi jika dihadapkan pada masalah-masalah politik.

Berdasarkan Peraturan Bersama Menteri Agama dan Menteri Dalam Negeri Nomor 9 dan Nomor 8 Tahun 2006, rumah ibadah adalah bangunan yang memiliki ciri-ciri tertentu yang khusus digunakan untuk beribadat bagi para pemeluk masing-masing agama secara permanen, tidak termasuk tempat ibadat keluarga. Islam mengenal masjid, musholla, langgar, dan surau untuk menyebut tempat umat Islam melaksanakan ajaran agama, terutama untuk melaksanakan sholat lima waktu. Salah satu tujuan pendirian rumah ibadah dalam Islam adalah sebagai sarana beribadah dan dalam posisi melakukan ibadah, umat Islam akan berkumpul dan berada di dalam masjid. ${ }^{39}$ Dalam pandangan Islam, tempat ibadah (khususnya masjid) memiliki posisi yang sangat strategis, terutama untuk kegiatan-kegiatan dakwah, apalagi jika memperhatikan apa yang pernah dipraktikkan oleh Nabi Muhammad SAW dan para sahabatnya. Islam tidak mengenal pengkhususan masjid, karena setiap muslim dapat memasuki

${ }^{39}$ Adon Nasrullah Jamaludin. Agama dan Konflik Sosial: Studi Kerukunan Umat Beragama, Radikalisme dan Konflik Antarumat Beragama. (Bandung: Pustaka Setia, 2015), 168. 
masjid manapun yang diinginkannya dan memanfaatkan fasilitas yang dimilikinya. ${ }^{40}$

Kristen (Katholik dan Protestan) mengenal gereja sebagai tempat mereka melaksanakan ajaran-ajaran agama yang mereka anut. Secara terminologis, gereja dimaknai sebagai tempat berdoa dan melakukan upacara agama Kristen, bisa pula dipahami sebagai persekutuan, organisasi umat Kristen yang sama kepercayaan, ajaran, dan tata caranya. ${ }^{41}$ Di Indonesia terdapat beberapa jenis gereja yang pengelompokannya dilakukan berdasarkan empat aliran utama, yaitu Gereja Katolik Roma, Gereja Protestan, Gereja Ortodoks dan Gereja Pantekosta.

Hindu mengenal Pura sebagai tempat para penganutnya untuk melaksanakan ibadat atau ajaran agama yang mereka anut. Secara etimologis, Pura berasal dari kata 'Pur' yang berarti: kota, benteng, atau kota yang berbenteng. Ini memang sesuai dengan realitasnya, karena Pura yang ada memang selalu dikelilingi bangunan yang berbentuk benteng atau tembok atau pagar yang besar dan tinggi. Pura dibangun sebagai sarana untuk menggiring rasa kedekatan diri pada Tuhan, untuk memudahkan konsentrasi pikiran karena di dalamnya simbol-simbol sinar kekuasaan Tuhan akan tersirat. ${ }^{42}$ Adapun rumah ibadat agama lainnya adalah Vihara atau Klenteng yang merupakan tempat ibadat orang-orang yang menganut ajaran agama Buddha, Konghucu, dan Taoisme. Vihara merupakan tempat ibadat dalam agama Buddha yang secara arsitektural lebih bernuasa lokal, sedangkan Klenteng sangat berkonotasi Tionghoa (China).

Pendirian rumah ibadah di Negara yang majemuk seperti Indonesia merupakan sesuatu yang dilematis. Satu sisi pendirian

\footnotetext{
${ }^{40}$ Isma'il R. Al-Faruqi dan Al-Faruqi, Lois Lamya. Atlas Budaya Islam, terj. Ilyas Hasan. (Bandung: Mizan, 1998), 185-186.

${ }^{41}$ Adon Nasrullah Jamaludin. Agama dan Konflik Sosial: Studi Kerukunan Umat Beragama, Radikalisme dan Konflike Antarumat Beragama. (Bandung: Pustaka Setia, 2015), 175.

${ }^{42}$ Ibid., 181.
} 
rumah ibadah merupakan hak setiap warga negara sebagai bentuk implementasi ajaran agamanya, tetapi di sisi lain akan menimbulkan konflik dengan warga negara yang lain. Terkait dengan ini, pemerintah mengeluarkan Peraturan Bersama Menteri Agama dan Menteri Dalam Negeri Nomor 9 dan Nomor 8 Tahun 2006 tentang Pendirian Rumah Ibadah di Indonesia. Dalam SKB ini diatur bahwa pendirian rumah ibadah harus mempertimbangkan pendapat kepala perwakilan Departemen Agama setempat. Terdapat beberapa persyaratan yang harus dipenuhi dalam mendirikan rumah ibadah, yaitu:

1. Keperluan nyata dan sungguh-sungguh berdasarkan komposisi jumlah penduduk bagi pelayanan umat beragama yang bersangkutan,

2. Memenuhi persyaratan berupa daftar nama dan KTP pengguna rumah ibadah paling sedikit 90 orang dan dukungan masyarakat setempat paling sedikit 60 orang, rekomendasi tertulis kepala departemen agama kabupaten/kota, dan rekomendasi tertulis Forum Kerukunan Umat Beragama (FKUB).

Selain syarat di atas, berdasarkan SKB Menteri tentang Pembangunan Rumah Ibadah di atas juga mensyaratkan bahwa hak pembangunan rumah ibadah ini hanya berlaku bagi agamaagama yang telah diakui secara sah oleh negara Indonesia secara konstitusional. Artinya bahwa agama yang tidak diakui oleh negara seperti halnya Ahmadiyah tentu akan sangat sulit atau bahkan dapat dikatakan tidak akan memperoleh izin untuk membangun rumah ibadah di Indonesia. ${ }^{43}$

\section{Kronologis Konflik Rumah Ibadah di Kota Jambi}

Sebagaimana disampaikan sebelumnya bahwa pluralitas agama sebuah wilayah berpotensi besar menimbulkan konflik. Hal

${ }^{43}$ Caveat, Freedom of Religion in Indonesia: Multiple Choicesnot Short Answers, Indonesian Monthly Human Rights Analysis. (09/ II, February 2010), 4.

98 | TAJDID vol. 19, No. 1, Januari - Juni 2020 
ini karena masing-masing agama cenderung ingin mendominasi kehidupan masyarakat melalui implementasi ajaran agamanya. Rumah ibadah yang menjadi tempat pelaksanaan ajaran-ajaran agama menjadi sumber konflik utama dalam konflik agama. Fenomena ini tentu saja dapat dilihat dari beragam perspektif yang salah satunya menyatakan bahwa rumah ibadah menjadi simbol komposisi penduduk dan dominasi kekuasaan. Semakin banyak rumah ibadah mengindikasikan komposisi penduduk yang besar pemeluk agama tertentu. Jadi tidak mengherankan jika banyak terjadi konflik mengenai pendirian tempat ibadah di berbagai wilayah Tanah Air.

Pada konteks dominasi pluralitas yang menyebabkan konflik pendirian rumah ibadah, apa yang terjadi di Kota Jambi sebagai wilayah majemuk juga mengemuka dengan hal yang sama. Sebagaimana diketahui bahwa pada awalnya Kota Jambi dikenal sebagai tempat pelabuhan ekspor bagi produk-produk daerah pedalaman Minangkabau, seperti emas, lada dan produk hutan Jambi sendiri. Pada tahun 1942, seiring dengan peralihan kekuasaan ke Kolonial Belanda ${ }^{44}$ yang memperkenalkan karet dan minyak bumi, maka Kota Jambi berubah menjadi tempat pelabuhan ekspor produk-produk dari Jambi sendiri, terutama karet. Akibatnya, perekonomian Kota Jambi mengalami peningkatan yang signifikan dibandingkan di masa-masa sebelumnya. Keadaan ini tentu tidak hanya berdampak pada kesejahteraan masyarakat Kota Jambi, tetapi juga berimplikasi pada derasnya arus pendatang yang masuk. Sehingga demografi penduduk Kota Jambi berdasarkan etnis cukup beragam, mulai Jawa, Sunda, Palembang, Batak, Minang, Bugis, Banjar, Arab, India dan China, dan etnis Melayu. ${ }^{45}$

44Benny Agusti Putra. Sejarah Melayu Jambi dari Abad 7 Sampai Abad 20. Jurnal Tsaqofah \& Tarikh, Vol. 3, No. 1, Januari-Juni, 2018. Lihat juga https://jambiprov.go.id/profil-sejarah-jambi.html.

${ }^{45}$ Lindayanty. Jambi dalam Sejarah 1500-1942. (Jambi: Dinas Kebudayaan dan Pariwisata Provinsi Jambi, 2013), 209. 
Meskipun terdiri dari beragam etnis atau dikenal sebagai masyarakat majemuk, namun sepanjang sejarahnya belum pernah terjadi konflik horizontal di Kota Jambi. ${ }^{46}$ Secara teoretik memang dikatakan bahwa pluralitas yang melekat pada sebuah bangsa atau wilayah berpotensi menyebabkan perpecahan atau konflik di antara masyarakat yang ada di dalamnya. ${ }^{47}$ Tidak hanya dari sisi etnis, keragaman dari aspek agama juga melekat pada Kota Jambi. Secara umum dapat dikatakan bahwa sebagai ibukota sekaligus juga sebagai miniatur provinsi, penduduk Kota Jambi menganut beragam agama, yaitu Islam, Kristen, Katholik, Hindu, Budha dan Khonghucu. Penting untuk menjadi catatan laina adalah bahwa etnis Melayu yang menjadi mayoritas di Kota Jambi adalah penduduk Muslim.

Secara historis, Kota Jambi walaupun belum pernah terjadi konflik horizontal, konflik-konflik kecil masih terjadi, terutama terkait dengan pendirian rumah ibadah agama yang dikategorikan minoritas di Kota Jambi. Konflik antara agama Islam dengan agama Kristen, khususnya Katholik, di Kota Jambi terjadi seiring dengan diperolehnya kemerdekaan Indonesia. Pasca Tahun 1945, para pejuang kemerdekaan menilai kehadiran orang-orang asing sebagai penjajah atau lawan, termasuk orang-orang Kristen akibat dari penjajah Belanda yang menyebarkan ajaran agamanya di Jambi dan Indonesia secara umum. Agama Kristen dianggap sebagai bagian dari Belanda karena disokong penuh selama masa penjajahan, sehingga harus pula angkat kaki dari Bumi Pertiwi. Ketika mendengar kondisi menyedihkan di Tanah Air, Pastor Hoogeboom yang sedang berada di Malaysia segera kembali ke Jambi awal 1949. Hoogebom berusaha mencegah para pejuang kemerdekaan yang akan mengambil alih dan menguasai tanah dan bangunan yang sudah dimiliki misi sebelum perang. Hoogebom

${ }^{46}$ Ibid., 6.

${ }^{47}$ Nasikun. Sistem Sosial Indonesia. (Jakarta: Rajawali Press, 2008), 8. 
meyakinkan para pejuang dan Pemerintah Indonesia, bahwa Misi Katolik tidak identik dengan Pemerintah Belanda. ${ }^{48}$

Terkait dengan konflik pendirian rumah ibadah, konflik pertama terjadi pada tahun 1957 ketika Pastor Hoogeboom mulai merintis gereja di lokasi baru. Izin pembangunan gereja baru yang permanen diperoleh dari Wali Kota R Soedarsono dengan surat izin bangunan (Bouvergunning) Nomor 191/5/57 tanggal 7 Oktober 1957. Namun demikian, Wali Kota Jambi memerintahkan penundaan sementara karena sedang ada peninjauan kembali rencana tata ruang kota. Penundaan itu disampaikan melalui surat Nomor 4630 tanggal 25 November 1957. Saat itu, partai politik mempunyai peran dalam pemberian izin pendirian rumah ibadat. Hanya satu partai-dari sembilan partai politik yang diakui pemerintah_yaitu Masyumi, yang tidak bersedia memberikan izin pendirian gereja yang permanen. Namun, atas kegigihan Pastor Hoogeboom, pembangunan gereja bisa dilanjutkan. Atas kebaikan Gubernur Yusuf Singadikane, seluruh partai bersedia menyetujui, dan Gubernur memberikan izin pendirian gereja yang permanen. Dengan mendapatkan izin tersebut, Pastor Hoogebom semakin bersemangat mencari dana dari para donatur. Pada akhirnya, gereja selesai dibangun dan diresmikan oleh Uskup Palembang, Mgr. Yosef Soudant, SCJ pada 12 Juli 1964. Itulah gereja di Jalan Raden Mattaher yang tetap megah berdiri sampai sekarang. ${ }^{49}$

\section{Pola Konflik Pendirian Tempat Ibadah di Kota Jambi}

Studi mengenai pola konflik keagamaan merupakan kajian yang luas dan menyangkut banyak aspek, yaitu jenis konflik, tingkat

${ }^{48}$ Aulia Kristina dan Ulul Azmi. Gereja Katolik ST. Teresia Kota Jambi $1935-$ 2011. Jurnal Ilmiah Istoria, Vol.3, No.1, April, 2019. Lihat Juga https://www.parokiteresiajambi.com/sejarah-gereja/ (Sejarah Gereja ST. Teresia Jambi.

${ }^{49}$ https://www.parokiteresiajambi.com/sejarah-gereja/ (Sejarah Gereja ST. Teresia Jambi. Lihat juga https://recisfmmjambi.com/profil/detail/1/sejarah, dan http://wikimapia.org/19966188/id/Sekolah-Xaverius-Jambi-Ta-TongHsieh-Hsiao. 
atau frekuensi konflik, perkembangan dan persebaran konflik, isu penyebab konflik, pelaku, dan dampak yang ditimbulkan konflik. ${ }^{50}$ Berdasarkan penelusuran yang dilakukan Takdir, pola-pola konflik agama yang terjadi di Indonesia sebagian besar mengarah pada dua jenis insiden, yaitu aksi damai berupa protes tanpa pertikaian dan aksi kekerasan berupa tindakan yang berakibat pada jatuhnya korban jiwa manusia atau kerugian harta benda. ${ }^{51}$ Adapun Muqoyyidin membagi pola konflik antar umat beragama di Indonesia menjadi tiga pola besar; Pertama, konflik antar umat beragama yang berbeda, contoh: kasus pelarangan pembangunan tempat ibadah. Kedua, konflik antar satu umat agama dengan kelompok yang dicap sebagai kelompok sesat, contoh: kasus kekerasan terhadap kelompok Ahmadiyah. Ketiga, konflik inter umat beragama yang berbeda dalam pemahaman, contoh: konflik antar aliran sunni dan syi'i. ${ }^{52}$

Terkait dengan pendirian rumah ibadah di Kota Jambi sebagai salah satu wilayah plural di Provinsi Jambi, pola terjadinya konflik menyangkut aspek isu penyebab konflik serta perkembangan dan persebarannya. Salah satu konflik pendirian rumah ibadah di Kota Jambi adalah penyegelan Gereja Huria Kristen Batak Protestan (HKBP) Syalom Aurduri di Penyengat Rendah, Jambi. Kejadiannya berawal dari kehadiran para tokoh agama Kristen Batak yang datang ke daerah Penyengat Rendah Kecamatan Telanaipura Kota Jambi dengan modus pemberian sembako untuk masyarakat pada tahun 1980, dalam konteks bantuan musibah banjir ketika itu. Masyarakat yang menerima sembako, semuanya beragama Islam, menandatangani lembaran kertas penerima sembako. Selanjutnya, tanpa sepengetahuan masyarakat, lembaran tandatangan penerima sembako tersebut

${ }^{50}$ Muhammad Takdir. Identifikasi Pola-Pola Konflik. Agama dan Sosial. Ri'ayah, Vol. 02, No. 01, Januari-Juni 2017, 45-64.

${ }^{51}$ Ibid., 54.

${ }^{52}$ Andik Wahyun Muqoyyidin, Potret Konflik Bernuansa Agama di Indonesia (Signifikansi Model Resolusi Berbasis Teologi Transformatif), ANALISIS: Jurnal Studi Keislaman, 2013, Volume XII, No. 2 Desember 2012, 315-340. 
disalahgunakan oleh Kelompok Tokoh Agama Kristen Batak untuk persyaratan pendirian balai pertemuan agama Kristen di daerah tersebut, sebagai persyaratan maupun bukti dukungan masyarakat setempat. Sebelumnya, di lokasi yang sama, juga telah didirikan Taman Kanak Kanak (TK) Pelangi untuk anak-anak Kristiani yang merupakan embrio awal dari balai pertemuan yang akan didirikan tersebut. Balai pertemuan ini lama kelamaan disulap menjadi gereja yang lokasinya hanya sekitar 300 meter (menyeberangi jalan besar utama Aurduri) dari bangunan Masjid masyarakat setempat. Masyarakat setempat menolak kehadiran Gereja yang berdiri di wilayah pemukiman masyarakat yang beragama Islam sehingga menyebabkan konflik. Meski demikian, konflik tersebut tidak melahirkan anarkisme ataupun bentuk tindakan kekerasan lainnya terhadap minoritas pengguna Gereja tersebut. Kearifan lokal melalui seloko adat menjadikan kebiasaan masyarakat Melayu di Kota Jambi menyelesaikan perkara melalui mufakat bersama tokoh agama dan tokoh adat yang kemudian memberikan pemahaman kepada masyarakat setempat agar mengadukan persoalan tersebut ke pihak berwenang yakni lembaga adat dan pemerintah. Kasus ini pun akhirnya sampai ke Pengadilan Jambi bahkan sampai ke Mahkamah Agung yang menyeret pihak Pemerintah Daerah ke ranah hukum tersebut dengan penyelesaian bahwa gereja tersebut tidak memiliki izin sehingga aktivitas peribadatan di gereja tersebut dipindahkan ke gereja lain yang sudah mendapatkan izin dari pemerintah. Namun demikian, sampai hari ini bangunan Gereja tersebut masih berdiri kokoh dan baik, tidak satu pun masyarakat setempat yang berupaya melakukan pengrusakan dan atau semacamnya. ${ }^{53}$

Kasus konflik pendirian gereja kedua di Kota Jambi terjadi pada tahun 1993 di Simpang Tanyo, kawasan Simpang Rimbo, Kecamaran Alam Barajo. Kejadiannya berawal dari pembangunan

53 Wawancara peneliti dengan tokoh adat Kota Jambi, Datuk Azra’i Albasyari (Ketua Lembaga Adat Melayu Kota Jambi), LAM Kota Jambi, Kamis, 12 November 2020.

TAJDID vol. 19, No. 1, Januari - Juni 2020 | 103 
gereja oleh beberapa orang Kristen beretnis Batak pada sebidang tanah di wilayah yang dihuni oleh mayoritas muslim Jawa, Sunda, Bugis, dan Melayu Jambi, tetapi kebanyakan tanah di lokasi tersebut dimiliki oleh orang Melayu Jambi (Seberang Kota). Pada awalnya, keberadaan gereja ini diprotes oleh orang-orang Melayu yang kemudian diikuti pula oleh orang-orang Jawa. Sampai saat ini, kasus pembangunan gereja ini belum ditindaklanjuti oleh Pemerintah Kota Jambi selaku pihak yang berwenang menangani masalah ini. Meski mereka yang protes terus melakukan aksi penolakannya, tetapi masih tetap dalam koridor menunggu jawaban dari pihak berwenang. Para tuo-tuo tengganai ${ }^{54}$ setempat terus melakukan arahan agar tetap bersabar dan menahan diri untuk tidak melakukan hal-hal seperti pengrusakan, kekerasan dan sebagainya. Aktivitas peribadatan di gereja ini masih terus berjalan tanpa ada gangguan dan ancaman dari pihak mayoritas Muslim. ${ }^{55}$

Konflik ketiga terkait pendirian rumah ibadah Kristen di Kota Jambi terjadi di kawasan Jalan Lingkar Barat yang termasuk dalam wilayah Kotabaru yang berlangsung sejak tahun 1990. Kejadiannya berawal dari pembelian tanah milik orang-orang Melayu di kawasan ini yang dilakukan oleh sejumlah orang beretnis Batak dengan harga yang cukup mahal. Pada awalnya, pemilik tanah tidak tahu kalau di kawasan tersebut akan dibangun gereja, sehingga mereka tidak mempermasalahkan kegiatan pembelian tersebut. Akan tetapi, setelah tahu bahwa pembelian tanah mereka digunakan untuk pembangunan gereja, maka merekapun protes karena kawasan tersebut merupakan pemukiman yang dihuni oleh mayoritas muslim. Tidak ingin protes warga ini berlarut-larut yang tentu saja menghambat aktifitas peribadatan gereja, beberapa

${ }^{54}$ Tuo-tuo Tengganai adalah istilah untuk para orang-orang yang dituakan dalam daerah setempat di Kota Jambi. Tuo-tuo tengganai menjadi rujukan dalam permasalahan adat dan dimintai pendapat dan suaranya dalam memutuskan perkara yang terjadi di Kota Jambi.

55 Wawancara peneliti dengan tokoh adat Kota Jambi, Datuk Azra’i Albasyari (Ketua Lembaga Adat Melayu Kota Jambi), LAM Kota Jambi, Kamis, 12 November 2020. 
oknum pengurus gereja berinisiatif menawarkan sejumlah uang kepada warga agar tidak melanjutkan protesnya. Tawaran ini diterima oleh sebagian warga. Sebagian lagi tetap melakukan penolakan dan protes meski jumlah mereka kian berkurang. Di sisi lain, pihak pengurus gereja Gregorius Agung, secara diam-diam melakukan loby dan penyelesaian pengurusan persyaratan pendirian gereja tersebut. Akhirnya izin pendirian gereja di lokasi jalan Lingkar Barat Kenali Asam Bawah inipun dikeluarkan. Mendengar informasi ini, kelompok Muslim Melayu yang protes dan melakukan penolakan sebelumnya, mulai menarik diri dan akhirnya mengalah. ${ }^{56}$

Tidak berlanjutnya konflik-konflik agama terkait pendirian rumah ibadah di Kota Jambi ini menjadi pertikaian besar yang memakan korban patut mendapatkan apresiasi dari segenap komponen masyarakat. Hal ini karena secara sosiologis, Kota Jambi merupakan wilayah plural yang penduduknya terdiri dari beragam agama (Islam, Kristen, Katholik, Hindu, Budha dan Khong $\mathrm{Hu} \mathrm{Chu}$ ) dan suku (Melayu, Batak, Palembang, Jawa, Buddha, Madura, China, Arab, India). Pluralitas sebuah wilayah tentu saja berpotensi terjadinya konflik, sebagaimana yang banyak terjadi beberapa negara dan daerah yang masyarakatnya plural.

\section{Penutup}

Sebagai wilayah plural, Kota Jambi termasuk dalam wilayah yang berpotensi terjadinya konflik agama, khususnya terkait pendirian tempat ibadah. Terdapat tiga kasus konflik pendirian rumah ibadah yang pernah terjadi di Kota Jambi, yaitu di Kotabaru, Alam Barajo dan Telanaipura. Pola konfliknya adalah aksi damai yang dilakukan oleh kalangan masyarakat muslim terkait

56 Menurut tokoh adat Kota Jambi, Datuk Azra'i Albasyari (Ketua Lembaga Adat Melayu Kota Jambi), membenarkan bahwa mereka para pendemo sudah bisa menerima keberadaan gereja dan tidak akan melakukan aksi boikot atau semacamnya. Mereka tidak mau ribut. Tetapi mereka menitipkan catatan agar pihak gereja tidak melakukan penyebaran agama di sekitar lokasi. 
pendirian gereja di pemukiman yang dihuni oleh penduduk mayoritas beragama Islam. Konflik tidak berujung pada tindakan anarkis karena difasilitasi oleh pemerintah daerah dan tokoh-tokoh agama Kota Jambi.

\section{Daftar Pustaka}

Al-Faruqi, Isma'il R. dan Al-Faruqi, Lois Lamya. Atlas Budaya Islam, terj. Ilyas Hasan. (Bandung: Mizan, 1998).

Alganih, Igneus. Konflik Poso. (Kajian Historis Tabun 1998-2001). Jurnal Criksetra, Volume 5, Nomor 10, Agustus, 2016.

Amsal, Bakhtiar. Filsafat Agama, Wisata Pemikiran dan Kepercayaan Manusia. (Jakarta: Raja Grafindo Persada, 2009).

Agus, Bustanuddin. Agama dalam Kehidupan Manusia: Pengantar Antropologi Agama. (Jakarta: PT. Raja Grafindo Persada, 2006).

Badan Pusat Statistik. Kota Jambi dalam Angka 2019. Kota Jambi: BPS Kota Jambi, 2019.

Bagir, Zaenal Abidin dkk.. Laporan Tahunan Kehidupan Beragama di Indonesia Tahun 2008-2011. (Yogyakarta: CRCS UGM, 2011).

Caveat, Freedom of Religion in Indonesia: Multiple Choicesnot Short Answers, Indonesian Monthly Human Rights Analysis. (09/ II, February 2010).

Creswell, J. W.. Qualitative Inquiry and Research Design: Choosing Among Five Traditions (2nd ed.). Thousand Oaks, (London, New Delhi: Sage Publications, 2007).

Denzin, N. K., \& Lincoln Y. S.. Handbook of Qualitative Research (Dariyanto, Badrus Samsul Fata, Abi, \& John Rinaldi, Trans.). Yogyakarta: Pustaka Pelajar, 2009. (Original work published 2000).

Fisher, Simon dkk.. Mengelola Konflik: Ketrampilan dan Strategi Untuk Bertindak, (Jakarta: British Council, 2009).

Halim, Abdul \& HM, Pahrudin. The role of Local Wisdom as Religious Conflict Resolution in Jambi City. Walisongo: Jurnal Penelitian 
Sosial Keagamaan, Vol. 27, No. 2 (2019). 353-374. DOI: http://dx.doi.org/10.21580/ws.27.2.4358.

Hartani, Mallia. Analisis Konflik Antar Umat Beragama di Aceh Singkil, Jurnal Kolaborasi Resolusi Konflik, Volume 2, Nomor 2, 9399.

Haryanto, Sindung. Spektrum Teori Sosial; Dari Klasik Hingga Postmodern, (Yogyakarta: Ar-Ruz Media, 2012).

Ismiati, Hesni. Konflik Antar Warga di Tanjung Balai Asahan Sumatera Utara, Jurnal EmpirikaVol.2 No.1, Mei. 2017.

Jamaludin, Adon Nasrullah. Agama dan Konflik Sosial: Studi Kerukunan Umat Beragama, Radikalisme dan Konflik Antarumat Beragama. (Bandung: Pustaka Setia, 2015).

Johnson, Doyle Paul. Teori Sosiologi Klasik dan Modern. (Jakarta: Gramedia Pustaka Utama, 1998).

Kimball, Charles. When Religion Becomes Evil, (USA: Harper Collins, 2008).

Kinseng, Rilus A.. Konflik Nelayan, Jakarta: Yayasan Obor Indonesia-Departemen Sains Komunikasi dan Pengembangan Masyarakat Fakultas Ekologi Manusia Institut Pertanian Bogor, 2014).

Kustini dkk.. Efektivitas Sosialisasi PBM No.9 dan 8 Tahun 2006. (Jakarta: CV. Prasasti, 2009).

Kristina, Aulia dan Azmi, Ulul. Gereja Katolik ST. Teresia Kota Jambi 1935-2011. Jurnal Ilmiah Istoria, Vol.3, No.1, April, 2019.

Lindayanty. Jambi dalam Sejarah 1500-1942. Jambi: Dinas Kebudayaan dan Pariwisata Provinsi Jambi, 2013.

Lulops, Roxane S. and Dudley D. Chan. Conflict from Theory to Action. (USA: Allyn \& Bacon, 2000).

Marvasti, Amir B.. Qualitative Research in Sociology. (London: SAGE Publications, 2004).

Miles, M. B., \& Huberman, A. M.. Analisis Data Kualitatif (Tjetjep Rohendi Rohidi, Trans.). Jakarta: Universitas Indonesia Press, 1992. (Original work published 1984). 
Muqoyyidin, Andik Wahyun. Potret Konflik Bernuansa Agama di Indonesia (Signifikansi Model Resolusi Berbasis Teologi Transformatif), ANALISIS: Jurnal Studi Keislaman, 2013, Volume XII, No. 2 Desember 2012, 315-340.

Nasikun. Sistem Sosial Indonesia. (Jakarta: Rajawali Press, 2008).

Putra, Benny Agusti. Sejarah Melayu Jambi dari Abad 7 Sampai Abad 20. Jurnal Tsaqofah \& Tarikh, Vol. 3, No. 1, Januari-Juni, 2018.

Rasyid, Mohd. Peredam Konflik Agama: Studi Analisis Penyelesaian di Tolikara Papua 2015, Jurnal Afkaruna, Vol. 13 No.1 Juni 2017.

Safi, Jamin. Konflik Komunal: Maluku 1999-2000, Jurnal Pendidikan dan Sejarah, Volume 12 No. 2, Maret 2017, 33-44.

Susan, Novri. Sosiologi Konflik: Teori-Teori dan Analisis. (Jakarta: PT. Kencana Media Grup, 2019).

Sukamto, Amos. Ketegangan Antar Kelompok Agama Pada Masa Orde Lama Sampai Awal Orde Baru: Dari Konflik Perumusan Ideologi Negara Sampai Konflik Fisik, Jurnal Teologi Indonesia 1/1 (Juli 2013), 25-47.

Soekanto, Soerjono. Sosiologi: Suatu Pengantar. (Jakarta: PT. RajaGrafindo Persada, 2013).

Suaedy, Ahmad. Politisasi Agama dan Konflik Komunal: Beberapa Isu Penting di Indonesia. (Jakarta: The Wahid Institute, 2007).

Takdir, Muhammad. Identifikasi pola-pola konflik agama dan sosial. Ri'ayah, Vol. 02, No. 01, Januari-Juni 2017. 45-64.

Wirawan, Ida Bagus. Teori-Teori Sosial dalam Tiga Paradigma, Jakarta: Kencana Prenada Media Group, 2012.

Yin, R. K.. Studi Kasus: Desain dan Metode (M. Djauzi Mudzakir, Trans.) Jakarta: PT. Raja Grafindo Persada, 2004. (Original work published 1996).

Yunus, Firdaus S.. Konflik agama di Indonesia: problem dan solusi pemecahannya. Substantia, Vol. 16 No.2, Okotber 2014. 217228. Retrieved from http://substantiajurnal.org. 
https://nasional.kompas.com/read/2019/01/08/18584911/ada15-kasus-pelanggaran-hak-beragama-di-2018.

https://www.parokiteresiajambi.com/sejarah-gereja/(Sejarah Gereja ST. Teresia Jambi.

https://jambiprov.go.id/profil-sejarah-jambi.html.

http://wikimapia.org/19966188/id/Sekolah-Xaverius-Jambi-TaTong-Hsieh-Hsiao.

https://recisfmmjambi.com/profil/detail/1/sejarah. 